\title{
Arrantza prezioen bilakaera: merkaturatze-katearen analisia
}

The price evolution of fish products: an analysis of the marketing chain

Eneko Martin*, Ikerne del Valle, Kepa Astorkiza

Ekonomia Aplikatua V Saila, Ekonomia eta Enpresa Fakultatea (UPV/EHU)

*eneko.martin@ehu.eus

DOI: $10.1387 /$ ekaia.16316

Jasoa: 2016-05-11

Onartua: 2016-06-21

Laburpena: Lan honen helburu nagusia banaketa-katean zehar arrantza prezioen integrazio bertikala aztertzea da, eta horretarako agregazio-ikuspegi bat du oinarri. Ikuspegi hori jatorriko arrantza prezioen agregazio-indize sintetiko bat (JPI) eraikitzean oinarritua dago, eta ondoren arrantza prezioen indizearekin (API) eta Estatistika Institutu Nazionaleko (EIN) kontsumoko prezioen indizearekin (KPI) konparaketa egingo da.

Hitz gakoak: integrazio bertikala, merkaturatze-marjinak, prezio indizeak, arrantza merkatuak, errenten bilakaera.

Abstract: The main objective of this paper is to analyse the vertical integration of fish prices along the value chain from an aggregate approach. This approach is based on the construction of a synthetic aggregate index of fish prices in origin (JPI) for subsequent comparison with the index of fish prices (API) and the consumer price index (KPI) of the National Statistics Institute (INE).

Keywords: vertical integration, marketing margins, price indices, fish markets, evolution of incomes.

\section{SARRERA}

Arrain-harrapaketen mugapena handituz doan ingurunean, arrantza produktuen prezioak armadoreen (enpresa ekoizleak) eta arrantzaleen diru-sarreren oinarrizko osagai dira. Alde batetik, prezioen gehiegizko aldakuntzak ziurgabetasun- eta arrisku-iturri dira eta, epe luzera, eragin negatiboa dute inbertsio 
planetan eta arrantza sektorearen errentagarritasunean. Bestetik, diru-sarrerei dagozkien eragin negatiboak (kostuen aldakuntzek eta harrapaketen mugapenek sortutakoak) konpentsatu ahal izateko, arrantzaleek balio-katean zehar beharrezko prezioen gehikuntzak transmititzeko gauza izan behar dute. Hala, harrapaketen mugapen-programek, stocken iraunkortasuna lortzera zuzendurikoek, arrantzaleen artean onargarritasun-maila handiagoa izango lukete eta, beraz, arrakasta-aukera gehiago ere bai. Ondorioz, erauzketa-sektorearen errentagarritasuna zein stocken iraunkortasuna prezioen transmisio-mekanismoekin sendoki lotuak daude balio-katean zehar (jatorrikoa, handizkakoa, xehekakoa).

Eskuarki enpresa armadoreek eta arrantzaleek adierazten dute arrantza prezioen lehenengo salmentaren bilakaerak profil konstante samarra daukala eta fase jakinetan joera negatiboa ere bai; ostera, gero eta alde handiagoa dago jatorriko eta xehekako prezioen artean; prezio horiek, hurrenez hurren, harrapatzen dituzten espezien truke jasotzen dituzten prezioak eta arrain erosketaren truke kontsumitzaileak ordaintzen dituen prezioak izango dira. Azaldutakoa berretsia izatekotan, merkaturatze-katean lehenengo kate-mailaren ahultasun estrategikoaren froga egongo litzateke, eta baita goiko kate-mailarako mesedegarria den merkaturatze-marjina bat existitzearena ere. Gainera, jatorriko arrantza prezioekiko (JPI) erosketa-saskiko prezioaren edo kontsumoko prezioen indizearen (KPI) gehikuntzak aintzat hartuz gero, itzulbiderik ez duen puntu batera hel liteke, non sektoreak sortutako errenta ez litzatekeen nahikoa jarraipena bermatzeko. Hala ere, lerratuak izan daitezkeen ikuspuntuez haraindi, ez dago ikerlan ugari arestian azaldutako hipotesiak egiaztatuko dituenik arrantza sektorearen helburu den espezie-multzorako. Lan honek aipatutako hutsunea betetzea du helburu agregazio-ikuspegi batean oinarrituta, eta berori jatorriko prezioen indize sintetiko baten kalkuluan datza. Bigarren kate-mailan MERCASA sareko kideek pisu espezifiko nabarmena dute; izan ere, ostalaritza independentea eta antolatua, eta gizarte-sukaldaritzako enpresak elikagai freskoez hornitzen dituzte. Eta hirugarren kate-mailan, produktua kontsumitzailearenganaino daramaten merkataritza tradizionala, supermerkatuak eta sukaldaritza daude.

Agregazio-ikuspegiaren abantaila nagusia bere izaera sintetikoa da. Horrek osoko argazki dinamikoa izateko bidea ematen du, zeinak merkataritza-espezie ia guztiak hartzen dituen eta arrantza merkaturatze-sisteman izan litezkeen asimetriak agerian uzteko bidea emango duen. Horrela interpretazio elementu berriak eduki ahal izango dira, eta, aldi berean, gertaeren bertsio osoagoa eta konplexuagoa ere bai (agregazio-ikuspegiak, balio-katean barrena, prezioen transmisio-mekanismoan izan litezkeen ahultasunak ulertu eta horiei heltzeko aukera ematen du).

Prezioen transmisio-analisiak ekonomialarien erantzuna dira gora doan kezka sozial eta politikoaren aurrean, alegia, merkataritza-kateko mailen artean izaten diren prezio-shocken transmisio kopurua eta abiadura aztertzen dute. Horri dagokionez, kontuan izan behar da mailetako batean ger- 
Arrantza prezioen bilakaera: merkaturatze-katearen analisia

tatutako aldaketek transmisio-mekanismoetan ondorioak izan ditzaketela. Horrela, adibidez, Banaketa Modernoa (BM) deituriko taldeen ekimenek, hau da, portuetan zuzenean erosteak eta euren banaketa zirkuituak sortzeak, bitartekarien posizioak eta transmisio-mekanismoak alda ditzakete.

Elikagai-produktuen merkaturatze prezioen transmisioari buruzko literatura oso zabala da AEBko merkatuen kasurako, non historikoki merkaturatze-marjinen ikerketak hainbat azterlanetan arreta nabarmena izan duen, besteak beste: [5-8-15]; Europako merkatuetarako, aldiz, ezin da gauza bera esan, nahiko urria baita, adibidez: [13-14]; eta Espainiako estatuko merkatuetarako, askoz txikiagoa [9-10-11]. Gainera, salbuespenak salbuespen, Espainiako estatuko arrantza produktuetarako prezioen transmisioari buruzko azterlanak ez dira asko eta espezie zehatz gutxi batzuetara mugatu dira. Integrazio bertikalari buruzko Cruzen eta Ameneiroren lana [3] eta Jimenez eta Garcia del Hoyorena [7] gailentzen dira, lehenengoa, oilarrarena eta, bigarrena, barbarinarena.

Artikuluak hurrengo egitura du. Bigarren atalean merkaturatzearen antolakuntza instituzionala zehaztu da, hirugarrenean marko teorikoa, laugarrenean analisi enpirikoa gauzatu da eta bosgarrenean ondorioak bildu ditugu.

\section{MERKATURATZEAREN ANTOLAKUNTZA INSTITUZIONALA}

Espainiako estatuan, harrapaketen lehorreratzeetatik azkeneko kontsumitzailearengana doan antolakuntza ereduak ezaugarri berezietako banaketa kanala eratzen du. Lehenengoz, kontuan hartu beharra dago kalteberatasun handiko ondasun galkorren tipologia dela. Freskoaren salmentan, arrainak iraungitze-maila handia du eta harrapaketetatik kontsumitzailearenganainoko kanalizazioan zainketa berezi batzuk izan behar dira, tenperaturaren kontrolari eta prozesu osoa zabaldu behar deneko denbora-premiari dagokienez. Arrain freskoan adierazitako ezaugarri bereziak direla medio, normalean goitik beherako enkantean edo enkante holandarra deiturikoan burutzen da lehenengo salmenta. Artisau eta itsasbazterreko ontzidiek burututako lehorreratzeen kasuan, arrantzale-kofradiek egiten dituzte enkante horiek eta, industria ontzidiek burututako lehorreratzeen kasuan, dagozkien ekoizleen erakundeek [1]; lonjak dira normalean horretarako ezarritako gunea. Egoera jakinetan, administrazioak espresuki baimendutako zentroa izan daiteke kokaleku hori.

Adierazi den bezala, lehenengo salmenta goitik beherako enkante baten bidez gauzatzen da eskuarki, baina ez da beti bide hori erabiltzen [2-12]. Goitik beherako enkantea ez da metodo bakarra eta, beraz, arrain freskoaren salmentan bestelako kontratu-formulak ere egoten dira saltzaileen eta erosleen artean. Edonola ere, formularik erabiliena da aspalditik, balio-ga- 
lera tasa handia jasaten duten ondasun freskoen salmentara zein oso ondasun galkorren merkaturatzera ondo egokitzen baita. Besteak beste, loreen, barazkien, fruituen salmentan erabiltzen den prozedura da, eta bai arrainarenean ere. Prezioak eratzeko mekanismo mota horietaz baliatzen diren beste egoera batzuk ere badaude, esaterako, estatuko bonu subiranoen enkantea edo enpresa publikoen pribatizazio-prozesuetan erabilitakoak. Halaber, dendek erabiltzen duten beherapen sistemak prozedura bereko aldaera bati erantzuten dio. Arrain izoztuaren merkaturatzearen kasuan, iraungitzearen berehalakotasunaren arazoak dakarren zailtasuna ezabatzen da. Arrain izoztua hilabeteetan zehar gorde daiteke baldin eta kontserbazioa bermatuta badago, arrain freskoek daukaten ondasun berezi galkorraren ezaugarririk ez du eta. Ordezko arazoa hotz-katea mantentzeko beharra da eta, ondorioz, instalazio eta garraiobide egokien beharra ere bai. Beste alderdi batzuetan, merkaturatzean, arrain izoztuaren jokabideak hain galkorrak ez diren ondasunen jokaerarekin antz handiagoa dauka arrain freskoenarekin baino. Arrain salmentaren kasuan, enkantearen funtzionamendua sorta baten aurkezpenaren bitartez bideratzen da, eta enkantegileak ezarritako hasierako gehieneko eta gutxieneko prezio batetik abiatuko da; goiko erreferentzia-puntutik abiatuz gero, prezioa beheranzko norabidean mugituz doa, beherapen ibilbide horretan, erosleak aurretik zehaztutako gehieneko eta gutxieneko prezioen arteko bat onartu arte. Puntu horretatik aurrera, sorta horren enkantea eten eta erosleari egokituko zaio. Noizean behin enkantegileak finkaturiko gutxieneko mugara iristea gerta daiteke, erosle bakar batek ere esku hartu gabe; hortaz, sorta baztertuko da. Kontratuen teoriak azaltzen du, holandarra deritzon enkante eredu horretan, eskatzaileak ordaintzeko prest dagoen zenbatekoa zehazki adierazten duela eta eskaintzaileak bere ekoizpenak oreka-prezioetan saltzea lortzen duela.

Prezioak finkatzeko erabilitako sistema edozein dela ere, lehenengo salmenta Europar Batasunean (EB) administratiboki arautua dago eta estatu kideek arautze horren ezaugarriak euren egoeraren baldintza zehatzetara moldatzen dituzte. Espainiako estatuko kasuan azaroaren 27ko 1.822/2009 Errege Dekretuak arautua dago.

Merkaturatzearen antolakuntza instituzionalak hainbat maila ditu, lehorreratzeetatik azkeneko kontsumitzailearenganaino doazenak. 1. irudian maila horiek, esku hartzen duten eragileak eta elkarrekiko erlazioak erakusten dira. Hasieran, artisau ontzidietakoak direla, industria ontzidietakoak direla, arrantzaleak daude, eta harrapaketak lehorreratu ostean lehenengo salmenta burutzen dute. Salmentan, handizkako merkatariek, kontserbaeta eraldaketa-industriako eragileek, eta supermerkatuetako eragileek esku hartzen dute funtsean. Dena den, behar bezala baimenduak izan direnek ere parte har dezakete noiz edo noiz. MERCASA sareko kideek ez dute lehenengo salmentan esku hartzen, baina eginkizun inportantea daukate lehenengo salmentaren eta azkeneko kontsumoaren arteko erdiko fasean; 




1. irudia. Merkaturatzearen gobernantza eredua.

MERCASA sareko kideetan eskaintzaren zati handi bat biltzen da, bertako ontzidi lehorreratzeetatik zein inportaziotik datorrena. MERCASA sareko kideetatik pasatzen ez diren kanal independenteak ere aipagarriak dira.

Kanpo-sektoreak garrantzi handia du, Espainiako estatuko arrain-eskaria handia baita eta bertako ontzidietako harrapaketak ez baitira nahikoak berori asetzeko. Hortaz, eskariaren zati nabarmena inportatzen da. Azkenik, merkataritza tradizionala dago eta azkeneko kontsumitzailearengana heltzen den eskaintza osatzen du supermerkatuekin, ostalaritzarekin eta eraldatuen nahiz kontserben ekoizpenekin batera [4].

\subsection{Arrainaren lehenengo salmenta}

Lehenengo salmentaren antolakuntzari garrantzi berezia eman zaio banaketa- eta merkaturatze-kate multzoan. Administrazio publikoek prozesuaren kate-maila nagusitzat hartu dute. Lehenengo salmenta arautzeak jokoaren arauak ezartzea du helburu merkaturatze-kateko hasierako fasean. Lehenik, lehorreratzeak eta harrapaketak argiki ezarritako zenbait zentrotan biltzen ahalegintzen da arautzea, ongi zehaztutako ezaugarri-multzoa 
dutela bermatzen saiatuta. Harrapaketak eta lehorreratzeak gune-sail batean biltzearen lehenengo helburua da premiagabeko zentro andanetan gainjarritako zerbitzuak ugaritzetik eratorritako kostuak aurreztea; izan ere, langileak eta instalazioak ugaltzen dira funtzio bererako. Beste aldetik, harrapaketak sartzeko eta lehorreratzeko kontrolik eza ekiditen ahalegintzen da, eta legez kanpoko harrapaketen merkaturatzea bideratzeko aukera txikien sorrerari oztopoak jartzen ere bai.

Behin harrapaketen deskargarako gune-sail bat mugatuta, arautzeak lehorreratzeen osasun baldintzen kontrola du helburu. Norabide horretan, lehenengo salmenta burutzen deneko lonjek beharrezko zerbitzuen hornidura bermatzeko baldintzak bete behar dituzte. Horrela eskatzen zaie, besteak beste, datuak lortzeko eta transmititzeko ekipamendu informatiko egokiak izatea, doitasun pisaketa-sistemak prestatzea, etab.

Gainera, zentro horietan normalean lehorreratzeen esku jartzen dira helburu horretarako oinarrizko azpiegiturak, adibidez, kutxak, izotza, noizean behin hotz ganberak, hondakinen hustuketa, indarrean dagoen legeriak zehaztutako osasun kontrolak gauzatzeko bitartekoak, etab. Aldi berean, etapa horretan harrapaketen datuak eta erregistroak jaso behar dira, ondoren salmenta agirian islatu eta, era berean, lehorreratzeen kopuru ofizial bihurtuko direnak. Etapa horrexetan antzematen eta mugatzen dira errazen legez kanpoko lehorreratzeak, harrapaketa tamaina desegokiak edo horien beste edozein gorabehera. Halaber, etapa horretan trazabilitatearen ezaugarriak eta harrapaketen kalitateak deskribatuko dituzten elementuak finkatzen dira, merkataritza- eta zientzia-izenetik, harrapaketa-eremutik, tamainetatik eta abarretik hasita. Hitz batez, lehenengo salmenta-prozesua kontuzko eta oinarrizko fasea da merkaturatzean, oro har.

Arrantza administrazioak, legeak eskatutako baldintzetan, baimenak emateaz eta lehenengo salmentarako lonjen eta zentro baimendunen irekiera egiaztatzeaz arduratzen dira. Arrain bizia, freskoa edo hoztua denean, deskarga horiek eta lehenengo salmenta portuetako lonja tradizionaletan egiten dira eta, besterik ezean, zentro baimendunetan. Izoztu, ultraizoztu eta prozesatutako arrainen lehenengo salmenta zentro baimendunetan burutzen da. Arrainak, izoztuta edo prozesatuta, EBko hirugarren herrialdeetako itsasontzietako harrapaketak direnean, lehenengo salmenta estatu-lurraldeko zentro baimendunetan gauzatzen da. Inportazioetatik datozen arrainsortek jatorrizko herrialdeko harrapaketa-ziurtagiria behar dute eta egiaztapena aduanan egiten da. Esportazioen kasuan prozesua antzekoa da, baina kontrako norabidean.

Enkantean handizkako merkatariek, kontserba-egileek, bitartekari baimendunek eta, gero eta indar handiagoz, saltoki handietako eta supermerkatuetako ordezkariek esku hartzen dute. MERCASA sareko kideak dira eskurapen horien zati handia biltzen duen kate-maila. MERCASA sareko kideak kudeaketa mistoko erakunde publikoak dira, non kokatuta dau- 
Arrantza prezioen bilakaera: merkaturatze-katearen analisia

deneko udalek ere esku hartzen baitute. Funtsean Espainiako estatuko 23 merkatu nagusik osatzen dute MERCASA sarea, eta fruituak eta barazkiak bezalako ondasun galkorren eskaintza eta eskaria zentralizatzeaz arduratzen dira. Beraien helburua elikagai sistema egituratzea da, elikagai freskoen banaketari handizkako zerbitzua emanez, ekoizpenen merkaturatzea dagokien jatorrizko etorkiarekin erraztuz, xehekako merkataritza bere formatu guztietan sustatuz, ostalaritza independente edo antolatuari, edo gizarte-sukaldaritzako enpresei elikagai freskoen hornidura ziurtatuz. Adierazitako zereginak garatzeko, MERCASA sareko kideek erabiltzaileen eskura jartzen dituzte mota horretako ondasunen banaketaren jarduera osagarriak bermatzeko ezinbestekoak diren baliabideak (biltegiratze-, kontserbatze- eta hozte-baliabideak, karga eta deskarga logistika, hondakinen hustuketa eta osasun kontrola, etab.). Azken finean, ekoizpenaren lehenengo kate-mailaren eta azkeneko kontsumitzailearen eskariaren gogobetetzearen arteko loturak dakartzan arazoei irtenbidea ematen jarduten du banaketafase horretako esku-hartzaileen multzoak.
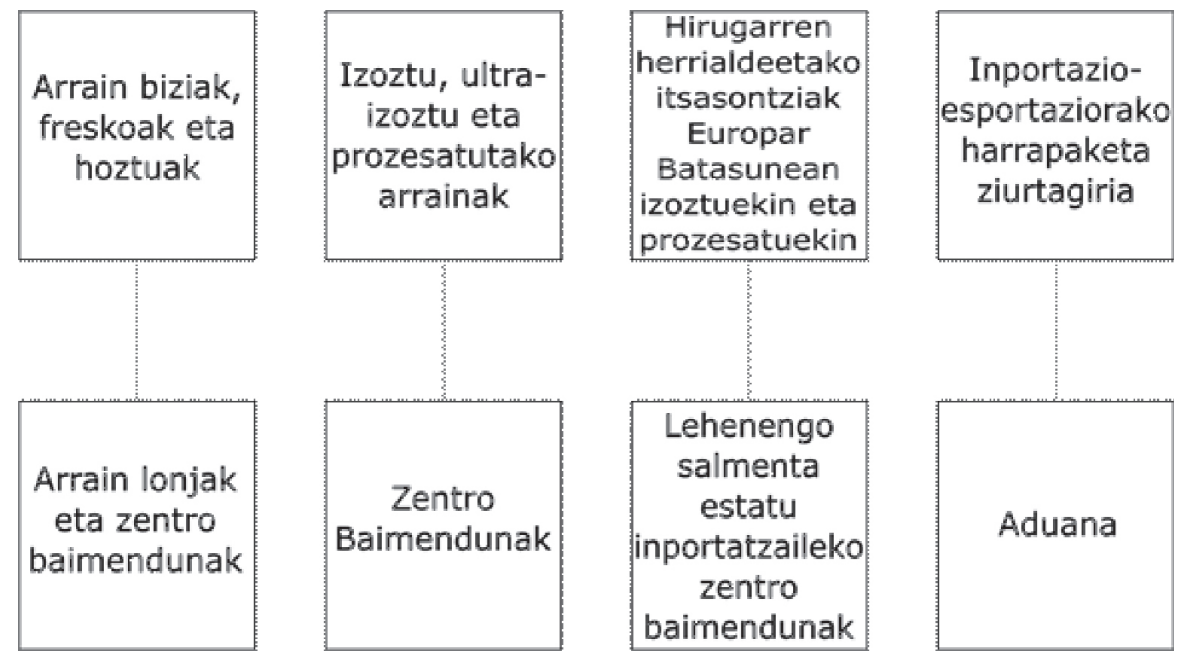

2. irudia. Espainiako estatuan lehenengo salmenta prozedura arautzea.

Arrain eskaria asetzeko beste kate-maila garrantzitsu bat inportazioen eta kanpo-sektorearen bidez abiarazten da. Arrain eskaria bertako ontzidiek eta EBkoek hornitzen duten eskaintza baino handiagoa da. Horregatik, Europar Erkidegokoak ez diren herrialdeetatiko harrapaketekin asetzen da eskariaren zati bat. Gure merkatuetarako harrapaketak hornitzen dituzten herrialde nagusien artean Txile, Namibia, Hegoafrika eta Frantzia daude. Handizkako merkatari baimendunak dira inportazio- eta esportazio-eragiketak burutzeko ardura hartzen dutenak. Kontuan hartu beharrekoa da ga- 
rraio-kostuak izugarri merkatu direla eta hotzeko garraio enpresa garrantzitsuak sortu direla, hain zuzen, hotzeko kargetan espezialistak diren abiazio enpresak. Kargaontzi horiek, aldeko baldintzetan, Afrikatik edo Amerikatik ozeanoan zeharreko bidaiak egiteaz arduratu eta arrainak 24 ordu baino gutxiagotan kokatzen dituzte MERCASA sareko kideetan nahiz banaketakanalen multzoan prezio lehiakorretan. Inportazio horien zati bat Europako beste herrialde batzuetara ere berresportatzen da. Handizkako merkatariak, eraldaketa-enpresak eta kontserba-egileak dira funtsean eginkizun horiek burutzeaz arduratzen diren figura eta erakundeak.

\subsection{Supermerkatu-kate handien garrantzia}

Supermerkatu-kateek arreta berezia merezi dute merkaturatze-prozesuan. Arrain freskoaren lehenengo salmentako merkatuetako prezioak sortzeko sisteman mailaz mailako aldaketa sortzen ari diren elementuetako bat dira. Euren kontratazio metodoak finkatuz doaz merkaturatzean duten gero eta aurrerabide handiagoaren bidez eta, halaber, kontratu-formula berriak gainjartzen ari dira ohiko kontratu ereduen gainean. Saltoki handiak salmenta metodoak aldatzen ari dira eta baliteke, prezio baxuetan saltzeko, arrain freskoaren bereizgarri galkorraz baliatuz joatea, beste ondasun batzuen salmentarako erakargarri erabiltzeko asmoz. Aldi berean, erauzketa-sektorearen eta kate horien arteko harremanak birformulatzen ari dira. Zalantzarik gabe, arrain freskoaren merkaturatze-sektorean ohiko orekak aldatzen ari dira, nola pisu erlatiboari hala duela gutxi arte handizkako merkatariek, merkataritza txikiak eta ekoizleek eurek izan duten eginkizunari dagokionez.

Kate handiek berariazko erosketa-zentralak sortu dituzte eta, halaber, zenbaitetan erosketa-zentral bakar bat partekatzen dute batzuen artean, euren merkataritza-helburuen arabera arrain freskoz hornitzeko. Hornitzaileak, batzuetan, handizkako merkatariak izaten dira, beste batzuetan, berriz, enpresa azpikontratatuak, portuetan arrain erosketaren funtzioa kontratupean euren gain hartzen dutenak edo portuetan edo arrain-haztegietan ekoizleekiko kontratu zuzenen arabera zuzenean egiten dutenak; MERCASA sareko kideetara ere jotzen dute eta bai, bitartekariek esku hartu gabe, enkante-lonjetan egiten den enkantera ere. Hori dela eta, oso erakunde malguak dira, jarraitzen dituzten merkataritza-estrategien arabera, erabaki egokienak hartzeko kontabilitate-tresna hertsiak eta eraginkorrak dituztenak eta arrazionaltasun ekonomikoaren hedapen zehatz bat daukatenak.

<Intermarché> supermerkatu-katearen kasuak aipamen berezia merezi du, hain zuzen, integrazio bertikaleko estrategia hartu du eta arrantza ontzidi handia sortu zuen, bere premien zati batez zuzenean hornitzeko balio izan diona. Hala eta guztiz ere, ez dio arrain freskoz hornitzeko beste ordezko iturri batzuez baliatzeari utzi. 
Arrantza prezioen bilakaera: merkaturatze-katearen analisia

Kate handiek banaketa forma tradizionalekiko abantaila konparatiboak dituzte; izan ere, eskaria bildu, maiz gainera baterako erosketa oligopsonioak sortu, jardueren integrazio formulak ezarri eta, arrantza tradizionalari dagokionez, eskala-ekonomia nabarmenak lortzen dituzte. Horrez gain, pixkanaka bitartekari batzuk ordezkatuz doaz, jatorri eta helmugaren arteko bidea laburtu dute eta balio-katean banatzeko errenta-kopurua gutxitu dute. Bestalde, kudeaketa- eta banaketa-prozesuari IKTak eta teknologia berriak txertatzeko gaitasun handiagoa dute, eta kate-multzoko erosketa- eta salmenta-prozesua homogeneizatu dezakete; horixe baita, hain zuzen, abantaila konparatiboetako bat banatzen duten edozein produkturen kanalizazioan.

Egiaz, arrantza banaketa-sektorea oraindik ez dago, adibidez, loreen sektorea dagoen integrazio mailetan. Baina joera antzekoa da eta, bi ondasunen izaeraren ezberdintasunak alde batera utzita, banaketa handia gobernantza eredu berria osatzen ari da; alegia, arrantza sektorearen jarduera aldatuz doa, ekoizpena antolatzeko eratik xehekako salmentaraino. Gobernantza-aldaketaren prozesu hori motelagoa da itsas-arrantza azpisektorean; akuikulturan, ostera, beraren azeleraziorako bereizgarri egokiagoak daude eta aurrerabidea nabarmenagoa da termino erlatiboetan. Akuikulturan, kontsumo handiko salmentan azaltzen diren aleen homogeneizazioa ia-ia osoa da; halaber, ekoizpen-kostuak konstante samarrak dira eta itsas-arrantzan baino ziurgabetasun gutxiagoren eraginpean daude.

Horrek guztiak sektoreko ekonomia-jarduera multzoaren antolakuntza instituzionalaren eredu berriak sortzen dihardu, zeinak, aldi berean, ekoizpena nahiz banaketa antolatzeko erak aldatzen ari diren. Kate handi horiek xehekako merkataritza tradizionala apurka ordezkatuz joan dira, eta bai balio-katea bai bertan sortutako errenten banaketa eratzeko modu berria ezartzen ari dira. Azkenik, truke desorekatua gauzatzen ari da merkaturatzean esku hartzen duten eragileen artean. Arrantza sektorean truke desorekatu hori areagotu egin da, erauzketa-sektoreak prozesuaren kostu gehienak bere gain hartu baititu eta merkaturatze-kateko balio erantsiaren zati nabarmenena, pixkanaka, banaketako eta azkeneko salmentako enpresa handi horietara mugituz joan baita.

\section{MARKO TEORIKOA}

Lan honetan agregazio-ikuspegi bat aztertu da eta merkaturatze-kateko prezioei buruzko informazioaren eta bitartekotza-marjinen transmisioaren ikerketa analizatu da, zenbaki indize haztatuetan oinarrituz. Horretarako, kontsumo nazionaleko prezioen indizea (KPI), eta Galiziako arrain fresko eta izoztuaren prezioen indizea (API) alderatuko dira Galiziako lonjako arrainaren prezioen indizearekin (JPI).

Kontsumoko prezioen indizea (KPI) [6], erosteko ahalmenaren adierazletzat hartuko dena, bizilekua Espainiako estatuko familia-etxebizitze- 
tan duen biztanleriak kontsumitutako ondasunen eta zerbitzuen prezio-multzoaren bilakaeraren neurri estatistikoa da. Familia Aurrekontuen Inkesta Jarraituak (FAIJ) eskaintzen du familiek kontsumoko ondasun eta zerbitzuetan dituzten gastuei buruzko oinarrizko informazioa. Haztapen horiek urtero eguneratu egiten dira FAIJaren informazio berria erantsita. Horrela, azken eguneratzearen ondorengo hamabi hilabeteetan, kontsumitzaileen ohituretan gertatutako aldaketak erakutsiko ditu KPIak. Bizilekua Espainiako estatuko familia-etxebizitzetan duen biztanleria-multzoa da erreferentzia estratua edo biztanleria taldea eta, beraz, berorren gastuen egitura oinarri izango da produktu adierazgarrienen hautaketarako eta baita berorien haztapenen kalkulurako ere. Biztanleriaren familiek kontsumoari eskainitako gastuek osatzen dute kontsumo arloa; hortaz, familia horiek egindako inbertsioak baztertuta geratuko dira. Biztanleriak dituen gastu errealak baino ez dira aintzat hartzen; ondorioz, horrek egotzitako edozein gastu-eragiketaren bazterketa dakar, besteak beste, autokontsumoari, autohornikuntzari, egotzitako alokairuari, gauzazko soldatari edo diruz lagundutako, adibidez, osasun- edo hezkuntza-kontsumoei dagokienez.

2001eko oinarria indarrean sartu arte, KPIak oinarri finkoko sistema deiturikoan funtsatzen zuen kalkulua; eta sistema horren ezaugarri nagusia zen erosketa-saskiko osagaiak (KPIan aukeratutako ondasunak eta zerbitzuak) nahiz beraien haztapenak aldagaitz mantentzen zirela oinarriak irauten zuen denboran zehar. 2001eko oinarria duen KPIarekin kalkulu-sistema berri bat hasi zen: dinamismoa eta gaurkotasuna ditu bereizgarri nabarmenenak. KPI gaurkotuagoa da, bere sistema metodologikoa etengabe aztertzen du eta, hobetzeko asmoz. Gainera, bere aurrekoak baino dinamikoagoa da, zeren desagregazio funtzionaleko zenbait mailatarako haztapenak urtero aztertzen baititu, eta era berean ahalik eta epe laburrenean merkatuko osagaietan hautemandako edozein aldaketa (produktu berrien agerpena dela, kontsumoko egiturako, edo udalerri- edo establezimendu-lagineko aldaketak direla) sartu ere bai.

Espainiako estatu, hamazazpi Autonomia Erkidego, berrogeita hamar probintzia, Ceuta, Melilla eta bi hiri horiek osatutako multzorako kalkulatzen dira kontsumoko prezioen indizeak (KPI). Era berean, KPIaren kalkulua 57 izenburutan (ogia, arrautzak, fruitu freskoak, edari alkoholdunak, tabakoa, behi-aziendaren okela...) zatikatu daiteke, eta horien artean arrain freskoa eta izoztua dago. Beraz, Galiziako arrain fresko eta izoztuaren prezioen indizearen kalkulurako (API), Autonomia Erkidegoen araberako izenburuen indizea erabiliko da, Galiziako Autonomia Erkidegorako arrain fresko eta izoztuaren izenburua aukeratuta. Artikulu honetan, indize hori (API) balio-kate barruko azkeneko kontsumoarekin lotu da, hau da, helmugarekin.

Azkenik, Galiziako lonjako arrainaren prezioen indizea (JPI) balio-kateko lehenengo kate-mailarekin (jatorria) erlazionatu da. Hori geuk sortutako indizea da eta Laspeyres-en indize kateatuaren bidez eraiki da, non 
Arrantza prezioen bilakaera: merkaturatze-katearen analisia

prezioen erreferentzia-aldia urtero aldatu den. 2002. urtean zehar oinarri-urtearekin bat egin du eta 2002az geroko urteetan, kontuan hartutako urtearen aurre-aurrekoa izango da. Batez besteko haztatuen bidez, haztapenak aldian-aldian eguneratuz, erosketa-saskiko oinarrizko osagai bakoitzaren indize elementalak eranstearen emaitza da Laspeyres-en indize kateatu hori, eta honela kalkulatu da:

$$
\mathrm{JPI}_{\mathrm{t}}=\prod_{\mathrm{k}=1}^{\mathrm{t}} \frac{\sum_{\mathrm{i}} \mathrm{p}_{\mathrm{i}}^{\mathrm{k}} \mathrm{q}_{\mathrm{i}}^{\mathrm{k}-1}}{\sum_{\mathrm{i}} \mathrm{p}_{\mathrm{i}}^{\mathrm{k}-1} \mathrm{q}_{\mathrm{i}}^{\mathrm{k}-1}}
$$

aldi arruntaren (t) eta oinarri-aldiaren (0) arteko erkaketa ezarriz, baina bitarteko egoerak aintzat hartuz.

Hortaz, agregazio-ikuspegi horrek zera du oinarri; alde batetik, lonjako arrainaren prezioen indizea (JPI) lortzean, espezie-multzo zabal baten lehenengo salmentako prezioen informazioaren bidez eraiki dena; eta bestetik, JPIa arrainaren prezioen indizearekin (API) eta kontsumoko prezioen indizearekin (KPI) konparatzean, zeinak Estatistika Institutu Nazionalak (EIN) hilero zehaztu eta argitaratzen dituen.

Analisi konparatibo horrek bitartekotza-marjina agregatua hurbiltzeko bidea emango du, jatorriko (JPI) eta helmugako (API) arrantza prezioen arteko arrailatik abiatuta. Halaber, prezioen diferentzialaren aldakuntzaren adierazle sintetiko bat (JPI/KPI) emango du; prezio horiek enpresak bere outputen truke jasotzen dituenak (JPI) dira, bere inputen truke ordaindu beharrekoari (KPI) dagokionez. Era horretan, arrantza produktuen jatorriko prezioen diferentzialak (JPI), eta berori Galiziako arrantza prezioen indizearekin (API) eta kontsumoko prezioen indizearekin (KPI) erkatzeak Galiziako arrantza sektorearen erosteko ahalmen errealaren bilakaera analizatzea ahalbidetu du.

\section{ANALISI ENPIRIKOA}

Ikerketa honetan, jatorriko (lehenengo salmenta) eta helmugako (xehekakoa) arrantza prezioen arteko arrailaren denbora-bilakaera aztertu da, prezio sintetiko orokorren indizeak (jatorriko arrantza prezioen indizea eta helmugako arrantza prezioen indizea) oinarri izanda. Horrez gain, arrantza produktuen jatorriko prezioen eta kontsumoko prezioen indizearen (KPI) bilakaeraren arteko diferentzialetik abiatuz gero, enpresa armadoreen eta arrantzaleen errenta errealaren bilakaera analizatu da.

Horretarako Galiziako arrain fresko eta izoztuaren prezioen indizea (API) eta kontsumo nazionaleko prezioen indizea (KPI), zeinak EINk argitaratzen dituen, Galiziako lonjako arrainaren prezioen indizearekin (JPI) alderatu dira. Galiziako lonjako arrainaren prezioen indizea (JPI), 2002-2014 denboraldian 
harrapatutako 136 espezietatik, 36 espezietarako datuen bitartez eraiki da. 36 horiek harrapaketa guztien eta zenbateko osoaren $\% 90$ baino gehiago dira.

Lonjako prezioen indizea, JPI deritzona, kalkulatzeko, 2001eko oinarria duen Laspeyres-en indize kateatua erabili da, eta APIarekin eta KPIarekin alderatu ahal izateko, aipatutako indizeak oinarri berera (2001) aldatzeari ekin zaio lotura koefizientearen bidez. Jarraian, 3. irudian urteroko hiru indize horien (KPI, API eta JPI) konparazioa ikus daiteke.

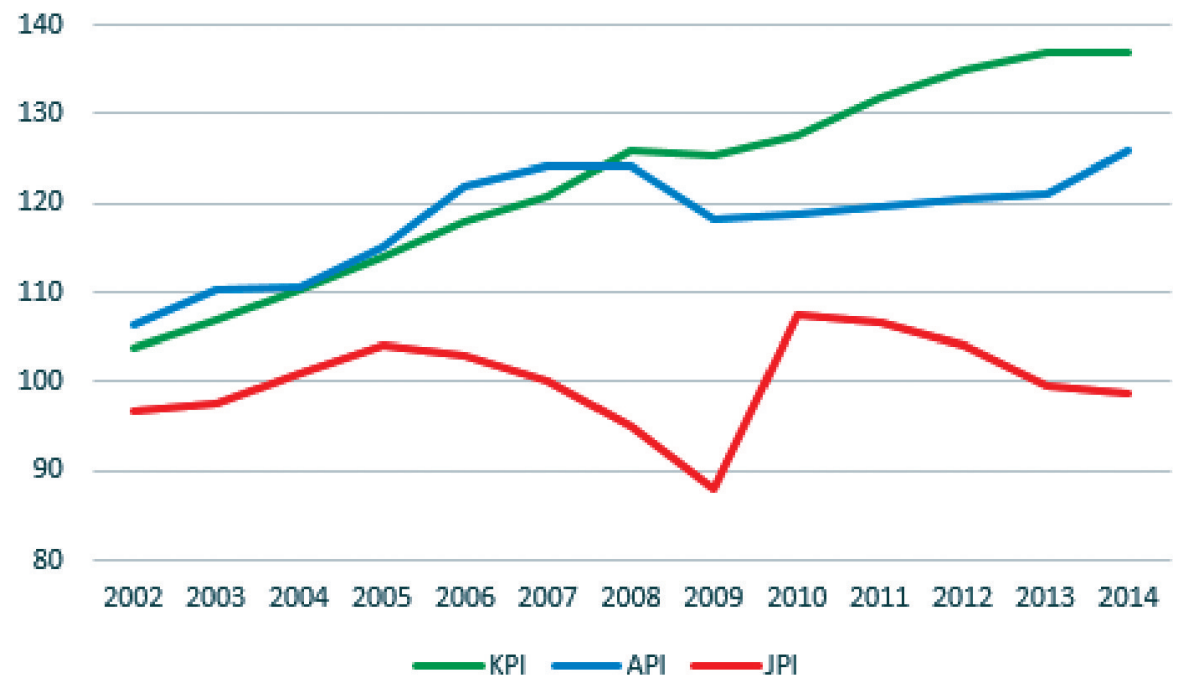

3. irudia. KPI, API eta JPI urteroko indizeen konparazioa.

Lonjako prezioen indizea (JPI) arrantza prezioen indizearen (API) azpian dago aztertutako denboraldi osoan. JPIa lehenengo salmentako ekoizlearen prezioei dagokie; APIa, berriz, azkeneko kontsumoarekin lotutako prezioei. Bien arteko arraila azaltzen dute merkaturatze fasean inplikatutako askotariko transakzio kostuek; adibidetzat garraio- eta bitartekotza-kostuak ditugu, merkatariek ezarritako merkataritza-marjinekin batera. Erauzketajardueraren ekoizpenen lehenengo salmentan sortzen diren prezioei merkaturatze-katean sortutako gehikuntzak batzen zaizkie. Arraina merkaturatzearen faseetan esku hartzen duten funtsezko eragileen jokabidean ikusitako interes handiko hainbat fenomeno nabarmentzeko aukera eman dute aztertu den aldiaren analisian lortutako emaitzek. Emaitzei esker, merkatu horretako eskaintzaileen eta eskatzaileen jokaeren bereizkuntza argia egin daiteke 2008ko krisia hasi aurreko fasean eta ondorengo denboraldian 2014ra arte. Krisiaren aurreko fasean, artikulu honetan 2002 eta 2008 artean, ikus daiteke ekonomia-multzorako kontsumoko prezioen indizea txikiagoa izaten ari zela eta azkeneko kontsumoari zegozkion arrantza produktuen pre- 
Arrantza prezioen bilakaera: merkaturatze-katearen analisia

zioen azpitik zegoela (ikusi 3. irudia). Ildo horretan ulertu behar da arrantza produktuen eskaria aski handia zela APIa KPI orokorraren gainetik manten zedin. Halaber, nabarmen daiteke arrain eskariak balio-katearen funtsezko zati bat eskuratzeko aukera eman diola merkaturatze-kateari. Aldi horretan gauzatu den ereduak sektoreko jardueraren kostuen funtsezko zati gorakor bat erauzketa-faseari egokiarazi dio; merkaturatze-prozesuan esku hartzen duten gainerako eragileak, ordea, erauzketa-sektoreari eta kontsumoko prezioen indizeari (KPI) dagokienez, maniobra-tarte handia irabaziz joan dira 2005etik apurka-apurka. Aldi berean, emaitzek agerian utzi dute 2008ko krisiak baldintza berriak sortu zituela aztertu diren arrantza merkatuetan. Aldaketak egiaztatu du 2005ean $(104,04)$ hasitako lonjako prezioen indizearen erortzeak, $2007(100,11)$ eta $2009(87,82)$ artean erortze aske bihurtu zenak, erauzketa-sektoreari eta arrantzaleei ohiz kanpoko eran kalte egin ziela. 2007 eta 2009 bitarteko erortze hori askoz ere handiagoa izan da gainerako arrantza merkaturatze-kateak jasan duen erortzeari dagokionez.

Adierazitakoaren arabera, deskribapen orokorraren barnean, JPIaren kasuak arreta berezia merezi du, gainerako merkaturatze-jarduera oinarritzen den azpisektorea da eta. Erauzketa-sektorea adierazten duen indizearen bilakaera 4 azpifasetan bana daiteke, erauzketa-sektoreak balio erantsia hartzearen egoerari dagokionez daukaten garrantzia kontuan izanda. Aztertutako 2002-2005 denboraldiko lehenengo urteetan, JPIaren indizean joera gorakorra zegoen eta, denboraldi horretan, erauzketa-sektorea balio erantsiaren marjinaren zati proportzional handi batera heldu da merkaturatzean; era berean, fase horretan indizeen multzoa, API zein KPI, bide gorakor bati jarraitu zaio. Termino absolutuetan zein erlatiboetan, esan daiteke analizatutako denboraldi osoan zehar erauzketa-sektorerako etapa mesedegarriena izan dela, merkaturatze azpisektoreko balio-katearekiko parte-hartzearen ikuspuntutik. 2005etik aurrera, JPI indizean 2009ra arte iraun zuen joera aldaketa hasi zen; behera doan bide horretan, 2007an joera beherakorra areagotu zen 2009an punturik baxuenera iritsi arte. Horixe da beste adierazleekiko distantziak gehien zabaldu direneko aldia. Fase horretan, merkaturatze-katean kaltetuena erauzketa-sektorea izan da, egoerak okerrera egin baitu termino erlatiboetan eta absolutuetan. Denboraldi horretan, sektoreko mantentze-kostuen pisuaren zati proportzionala erauzketa-sektoreari egokitu zaio, alegia, balio-katean kaltetuena izan denari. 2009 eta 2010 bitartean adierazle horren susperraldi azkarra eta nabarmena gertatu zen, bere erregistro historiko onenaren gainetik kokatuz. Baina 2010etik aurrera joera berriz aldatu zuen eta aztertutako aldiaren amaierara arte iraun duen beheranzko joera iraunkorrari berriro hasiera eman zion, laburra, baina handia ere izan zen hobekuntzan berreskuratutakoa galduz eta beste bi indizeekiko aldeen handiagotzera itzuliz.

Denboraldi horretan Galiziako arrantza sektorean ari izan diren ontzien kopuruaren datuetatik abiatuta, denboraldi berean jarduera bertan behera uztea 
erakusten duen 1. taula eraiki da ${ }^{1}$. Ontzien desagertzeak azpisektore guztiei ez diela neurri berean eragin egiazta daiteke datu horietan. Ikertutako kasuan, batez ere kaltea jasan duen jarduera azpisektorea artisau-sektorea izan da, beste azpisektoreetan izan den baino ontzi kopuru handiagoa desagertzeak erakutsi duenez. Enpresen ikuspegitik, artisau-sektorea ahulena da; gainera, ustez baldintza marjinaletan ari izan ziren ontziek (ekonomia ziklo hedakorreko goifasean merkatu baten eskari baldintzez baliatuz jarduerari eusten ziotenek) azkenean jarduera bertan behera utzi zuten. Gauzak horrela, ontzi gutxiagok jardungo dute eskaria asetzeaz arduratuko diren harrapaketak burutzen.

2008ko krisiaren ondorioz sortutako aldaketan irudikatu den elementu garrantzitsu bat joeraren alderantzikatzea da, aurreko egoerarekin alderatuta. Kontsumo orokorreko prezioen indizearen eta beste bi arrantza adierazleen arteko arraila nabarmena jazo da. Krisiaren aurreko aldiak ez bezala, non arrain eskariak kontsumo orokorreko prezioen indizearen gainetik arrainaren prezioen adierazleari eutsi zion, honek arrantza produktuen kontsumoko prezioen indizeari, analisiak hartzen duen denbora guztian zehar atzean geratzen denari, aldea atera dio 2008tik aurrera. 2008 eta 2014 bitartean, arrainaren azkeneko kontsumoarekin lotutako prezioen indizea (API) sistematikoki KPIaren azpian kokatu da, baita ezohiko distantzian ere, krisiaren aurreko denboraldian nagusia zen ereduarekin erkatzen bada. Merkaturatze-kateak bere mozkin-tartea murriztua ikusi du krisialdian zehar. Indize horien gutxitzearen fenomenoak oso eragin nabarmena du merkaturatze-katearen multzoan, eta baita merkaturatze-katearen gailurrean ere.

Adierazi bezala, 2005 eta 2009 bitartean lonjako prezioen indizearen (JPI) gainbeheraren joera orokorra gertatu da; 2009 eta 2010 artean, al-

\footnotetext{
1 Arrantza sektoreak pairatu duen gaitz nabarmenetako bat baliabideen gehiegizko ustiatzea eta gehiegizko kapitalizazioa da. Horixe da gehiegizko esfortzu baten existentzia adierazteko modua, neurtzen den eran neurtzen dela, alegia, arrantza ontzien kopuruaren, ZP-tan neurtutako potentziaren edo GT-tan neurtutako edukieraren (erregistroko tonaje gordina) arabera. 1990eko hamarkadaren bigarren erdian eta 2000ko hamarkadaren lehen urteetan zehar, Europar Batasuneko (EB) Arrantza Politika Bateratuak (APB) bereziki esfortzu horren murrizketa zorrotzean jarri zuen arreta; izan ere, zegozkion programekin, egitura erreforma prozesu bat abiarazi zuen, zeina zegoen ontzidiaren zati nabarmen bat kentzera xedatua zen. Horretarako, sobera ziren ontziak desegiteko pizgarri handiak proposatu zituzten. EBk, bere aldetik, arrantzaleen lanbide-birmoldaketa gauzatzeko egitasmoak abian jarri zituen, baita arrantzaren menpekotasun osoa zuten eremuetako jarduera ekonomikoa zenbait pizgarriren bidez dibertsifikatzeko ere. Baina lan honetan aztertzen den denboraldiaren lehenengo zatiaren urteetarako, birdoitze egitasmoen zati handiena ordurako beteta zegoen. Hori dela eta, taula honetan ikusten den ontzidiaren jaitsierak merkatu baldintzetatik eratorritako ontzidiaren errentagarritasunarekin zerikusi handiagoa du, APBk EBn ontzidia berregituratzeko duen egitasmoarekin baino. Kontuan hartu den populazio-multzoaren baldintza teorikoek funtsean okerrera jo ez dutelako hipotesitik abiatzea onargarria da; aitzitik, lehenengo salmentako merkatuaren baldintzak aldatu egin dira, bereziki eskariaren jokabide aldaketak.
} 





diz, adierazle horren susperraldi azkarra eta handia jazo da. 2010ean serieko maila garaienera heldu zen, ziklo hedakorreko oparoaldi ekonomikoaren aldian izandakoa barne. 2010eko maila goren horretatik aurrera eta aztertutako aldiaren amaiera arte, JPIa gainbehera fasean sartu zen berriro. Erauzketasektorean ontzi kopuru txikiago batek asetzen zuen zegoen eskaria; hala ere, 2010 eta 2014 bitartean berriz adierazle horren joera alderantzikatu egin zen. Gorakadak, erauzketa-sektorean, arrantzaleen diru-sarreren eta erosteko ahalmenaren hobekuntza erlatiboa iragartzea ahalbidetzen zuen, baina 2010etik aurrerako gainbeherak berriz eragile horri egokiarazi dio merkaturatze-kate multzoko kargaren funtsezko pisua. Susperraldi iragankorra gorabehera, arrantzaleek arrantza sektorean balio-katearen gaineko euren parte hartze erlatiboaren hobekuntzarik lortu gabe jarraitu dute, arrantza produktuen merkaturatze-kateak KPIarekiko bere aurreko nabarmentzea galtzen jarraitzearekin batera. Arrantzaleek erositako ondasunek eta zerbitzuek KPIaren bideari jarraitu diote, baina beraien ekoizpenen salmentak JPIari jarraitu dio eta bien arteko aldea handituz joan da, 2009-2010 denboraldian izan ezik.

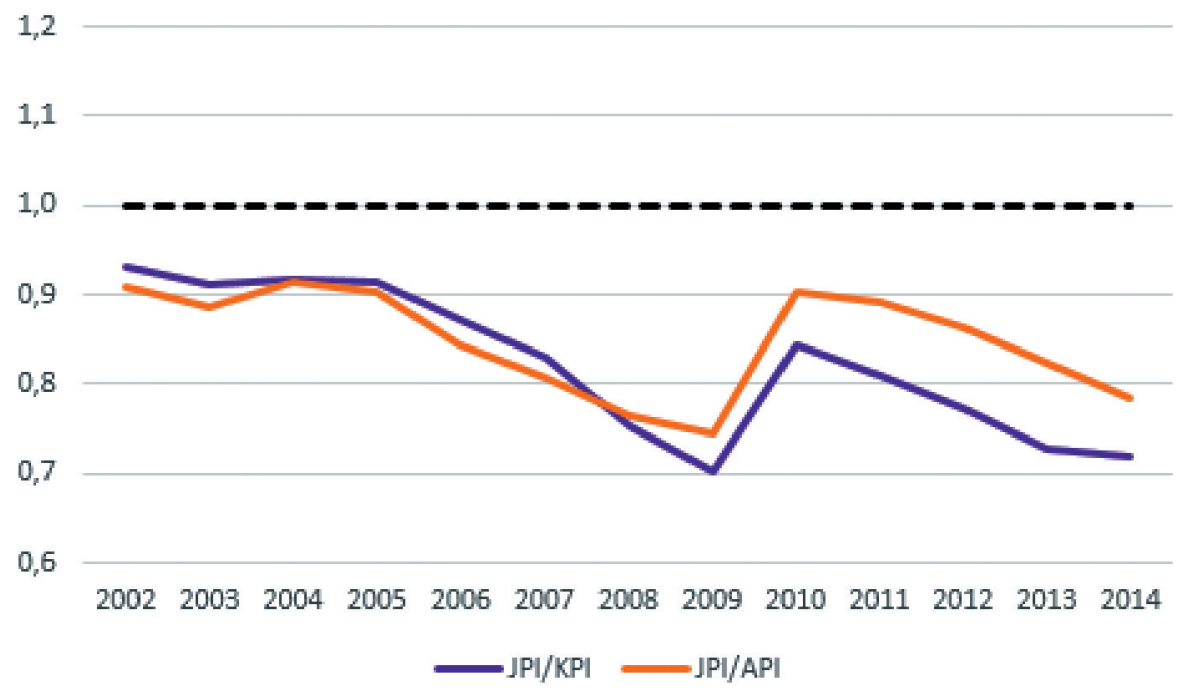

4. irudia. KPIarekiko eta APIarekiko JPIaren Urteko Ratioak.

Fenomeno bera atzemateko beste era bat, aurreko emaitzen zentzua argitzeko balio duena, aurreko adierazleetan oinarrituta eraikitako ratioen bidez ezar daiteke. Horiek 4. irudian erakutsitako JPI/KPI eta JPI/API ratioak dira. JPI/KPI ratioak lortu dituzten diru-sarrerekin arrantzaleen erosteko ahalmenaren mugimendu erlatiboak atzematea ahalbidetu du eta JPI/API ratioak merkaturatze-marjinan arrantzaleen parte hartzearen mugimendu erlatiboak atzematea ahalbidetu du. Bi indizeek aurreko analisia berresteko aukera eman dute, funtsean datu berberen arabera eraiki baitira, baina, gai- 
Arrantza prezioen bilakaera: merkaturatze-katearen analisia

nera, interes kontu batzuekin prozesua bera argitzea ahalbidetu dute. JPI/ API ratioa unitatea baino txikiagoa mantendu da analizatutako denboraldi osoan zehar, eta horrek agerian utzi du arrainen jatorriko prezioen eta azalera handiko zein xehekako saltokietako azkeneko salmentako prezioen arteko aldea, baita denboran zeharreko aldakuntza erlatiboak ere. Ekonomia zikloko fase hedakorrean zehar, ratio hori jaitsiz joan da 2002 eta 2008 bitartean, eta joera horren bidez, erauzketa-sektorearen parte hartze erlatiboaren txikiagotzea egiaztatuz joan da merkaturatze-sektoreari dagokionez. JPI/KPI ratioa, bestalde, unitatea baino txikiagoa mantendu da eta 2002 eta 2008 denboraldian zehar jaitsiz joan da, horrela ekonomiaren kontsumoko prezioen indizearekiko arrantzaleen erosteko ahalmenaren murrizketa adieraziz. Alabaina, 2002 eta 2008 bitarteko fasean JPI/KPI ratioa JPI/ API ratioaren gainetik mantendu da, beraien artean bereiz daitezkeen ondorio erlatibo batzuen existentzia adieraziz. Kontuan hartu beharrekoa da adierazitako denboraldian erauzketa-sektorea pisu espezifikoa galduz joan dela, bai ondasunak eta zerbitzuak erosteko ahalmenean, bai merkaturatze-katean sortutako diru-sarreren gaineko parte hartze erlatiboan. Hala ere, galera merkaturatze-katean sortutako diru-sarreren gaineko parte hartze erlatiboan handiagoa izan da denboraldi berean ondasunak eta zerbitzuak erosteko ahalmenean baino. Ondorio hori atera da indizeak eraikitzearen bidez lorturiko emaitzetatik. Krisia piztu ostean, jokabide eredua dagoeneko azaldu den norabidean aldatu zen. Krisiaren lehenengo fasean, 2008 eta 2009 urteen artean bi indizeak maila historiko baxuenetara jaitsi ziren. 2009tik aurrera bi indizeek 2010era arte baino iraun ez zuen goranzko joera nabarmen bati ekin zioten. Fase horretan, aztertutako gainerako denboraldian iraun duen dinamika berri bati hasiera eman zaio eta JPI/KPI ratioa ezaugarri du, zeina, ekonomia hedapenaren aurreko denboraldian ez bezala, JPI/API ratioaren azpitik mantendu den. Fase horretan, erauzketa-sektoreak, merkaturatze-sektoreari dagokionez, pisu espezifikoaren mailakako galerari berriro hasiera eman dio, aldi berean, merkaturatze-katean sortutako diru-sarreren gaineko parte hartze erlatiboan hierarkia galduz. Emaitza horietatik ondoriozta daiteke erauzketa-sektorearen eta arrantzaleen galera denboraldi berean ondasunak eta zerbitzuak erosteko ahalmenean handiagoa izan dela, bereziki, merkaturatze-katean sortutako diru-sarrerekiko parte hartze erlatiboaren gaineko ondorioekin erkatzen bada. Arrantzaleak eta erauzketa-sektorea gainerako jarduerak eta arrantza merkatuak bermatzen direneko habea dira. Hausnarketa horretatik abiatuz gero, JPI/ KPI adierazleak erakutsi duen bidea lotuta daraman ekonomia- eta sektorepolitikaren ondorioetatik hurbilago dagoen irakurketa egin daiteke. Adierazle horrek azpimarratu du lehenengo salmentako arrantza prezioen igoerak baino neurri nabarmen handiagoan gora egin duen erosketa-saskiko prezio-mailaren bide bati aurre egin diotela arrantzaleek eta erauzketa-sektoreak. Ondorioz, merkatuan erosteko ahalmenaren gainbehera handi baten aurrean daude. Horrek truke desorekatu baten ondorioak pairatu behar iza- 
tera daramatza, hain zuzen ere, azkeneko merkatuetan arrantza baliabideetatik lortutako errentaren zati esanguratsua galtzera.

3. irudian azaldutako emaitzekin koherentea da hori. 3. irudian ikus daiteke 2008 eta 2014 bitartean arrainaren azkeneko kontsumoarekin lotutako prezioen indizea (API) sistematikoki KPIaren azpian kokatu dela eta bai ezohiko distantzia batean ere, krisiaren aurreko denboraldian nagusi zen eredua kontuan hartzen bada. 2013 eta 2014 bitartean, lehengoratzefase baten hasiera ikus daiteke APIan; izan ere, joera aldatu eta goranzko bide bati ekin dio, zeinak, beharrezko daturik ezean, ezin duen analisi honetan proposatutako markoaz kanpoko interpretazio alternatiborik eduki.

Ez da ahaztu behar emaitzak lurralde-eremuan eta denboran mugatutako ikerketa-kasu bati dagozkiola. Horregatik, etorkizunean aldaketa horien iraupena iragartzea ez da erraza, baina beraien existentzia eta izan dezaketen interesa jasota uztea garrantzitsua da, emaitza bakana edo beste ikerketa-kasu batzuetan ere egiazta daitekeen fenomenoa den bereizteko. Oraindik gutxi aztertutako gai bati buruzko interes handiko galdera berriei ateak ireki dizkie.

\section{ONDORIOAK}

Erabilitako metodologiaren bitartez, espezie-multzo baterako arrantza prezio agregatuen bilakaeraren ideia argia eduki ahal izan da. Era berean, analisian argi agertzen hasi da arrantza negozioaren sistema-multzoa osatzen duen azpisektore bakoitzaren bilakaera, hau da, arrantza enpresak, arrantzaleak, merkaturatze azpisektorea eta kontsumitzaileak. Azaldu den metodologiari jarraiki, arrainaren balorizazio-kateko fase eta kate-maila bakoitzean sortutako diru-sarreren aldakuntzen ikuspegi argigarria ikus daiteke. Emaitzen bitartez, merkaturatzearen ezaugarri nagusietako batzuk agerian jarri dira 2008ko ekonomia krisiaren aurreko faseetan eta ondorengo urteetan, eta baita azpifase horietako bakoitzean sortutako baldintza partikularrak ere.

Adierazi bezala, 2002-2014 denboraldian lortutako emaitzek merkatu horretan esku hartzen duten eragileen jokabidean bi denboraldi bereizteko aukera ireki dute. Alde batetik, 2008ko krisiaren aurreko jokabidea dago eta, bestetik, 2008tik 2014ra doan bigarren denboraldia.

2002-2008 tartea hartzen duen fasean, arrantza produktuen azkeneko eskariaren bultzatzeak APIa KPI orokorraren gainetik mantentzea lortu du eta merkaturatze-kateak, bestalde, arrantza sistema-multzoan balio-kateko zati erlatibo garaiena atzematea. Bitartean erauzketa-faseak arrantza jardueraren kostuen funtsezko pisuari eutsi dio. Hala ere, gauzatutako analisiak nabarmendu du 2008ko krisiak, bere loratzearen ostean, ezaugarri desberdinak - eta neurri batean, ustekabekoak - zituen egoera sortu zuela, aztertutako arrantza merkatuetako aurrekariei zegokienez. 
Arrantza prezioen bilakaera: merkaturatze-katearen analisia

2008 eta 2014 bitarteko bigarren denboraldian dinamika orokor berria sortu da, merkatu horretan inplikatutako eragile guztietarako krisiaren eragin itzela ezaugarri duena. Krisiarekin batera hasitako fase horretako multzoan, arrantza sektorean inplikatutako indize guztiak era zorrotzean jaitsi dira merkaturatze-katearen multzoan. Gainera, joera aldaketak, krisiaren hasieraren ondorengo denboraldi osoan zehar, arrantza sistema analizatzeko erabilitako indize guztiak KPIaren azpitik mantentzera eraman du.

Indizeak 2009an euren minimora heldutakoan, dibergentzia berria hasi da krisiaren aurreko denboraldiari dagokionez. 2009 eta 2014 artean nabarmentzearen galera gertatu da merkaturatze-prozesuaren azken fasean, hain zuzen, banaketarenean, kontsumitzailearengandik hurbilen dagoen horretan. Azpisektore hori, krisia heldu baino lehen, onura handiena ateratzen zuena zen balio-kateko etekinen banaketan. 2009tik aurrera, ostera, erauzketa enpresek eta arrantzaleek euren parte hartzea hobetu dute etekinen banaketan, banaketa azpisektoreari dagokionez. Dena dela, analisian egiazta daiteke banaketarekiko arrantzaleen parte hartze erlatiboak ez dakarrela beraien diru-sarreren erosteko ahalmenaren hobekuntzarik. Balio-katean parte hartzea hobetzeari dagokionez emaitzek adierazi dutena adierazi dutela, gainerako indize guztiekiko KPIaren gehikuntza erlatiboak arrantzaleen eta erauzketa enpresen erosteko ahalmenaren galera ekarri du krisian zehar. Krisiak merkatu horretako eskuhartzaileen egoera erlatiboak aldatu ditu, baina horiek guztiek okerrera egin dute krisiaren aurreko denboraldiari dagokionez.

Aurreko konklusio horiek ikertutako kasuaren kokalekuaren berariazko norabideen ondorio ez direla egiaztatzeko eta emaitza horiek areago orokortu ahal izateko, beharrezkoak izango dira noranzko bereko ikerketakasu berriak.

\section{ESKER ONAK}

Ikerketa honek Ekonomia eta Lehiakortasun Ministerioaren diru-laguntza (ECO2013-44436-R) jaso du, Eusko Jaurlaritzaren eta Gizartearen Erronketara zuzenduriko I+G+b Estatuko Programaren esparruan ( $E r a-$ kundeak, Erregulazioa eta Politika Ekonomikoa» Ikerketa Talde Finkatua (GIC12/171)). Oker eta iritzi guztiak egileen erantzukizuna dira.

\section{BIBLIOGRAFIA}

[1] ASTORKIZA, K., ASTORKIZA, I. eta DEL VALLE, I. 2003. «La comercialización de la Pesca en la CAV». Itsas Memoria Revista de Estudios marítimos del País Vasco, 4, 489-498. 
[2] BURGUET, R. 2000. «Auction theory: A guided tour». Investigaciones Económicas, 24 (1), 3-50.

[3] CRUZ, I. eta AMENEIRO, M. 2007. «Transmisión vertical de precios en el mercado nacional de los productos pesqueros frescos». Revista de Economía Aplicada, 44, 85-107.

[4] DEL VALLE, I., MARTIN, E. eta ASTORKIZA, K. 2013. Vertical Integration and Price Transmission in the Spanish Fish Market. XXI EAFE Conference, Heriot-Watt University, Edinburgh.

[5] GOODWIN, B.K. eta HARPER, D. 2000. «Price Transmission, Threshold Behavior and Asymmetric Adjustment in the U.S. Pork Sector». Journal of Agricultural and Applied Economics, 32, 543-553.

[6] INSTITUTO NACIONAL DE ESTADÍSTICA. 2006. Madrid: INE. INEbase, Índice de Precios de Consumo (IPC). Base 2006, Metodología, http://www.ine.es/.

[7] JIMÉNEZ-TORIBIO R. eta GARCÍA DEL HOYO J.J. 2006. «Evidence of market price leadership in the Spanish red seabream value chain: Implications for fisheries management». Fisheries Research, 81, 51-59.

[8] KINNUCAN, H.W. eta FORKER, O.D. 1987. «Asymmetry in farm-retail price transmission for major dairy products». American Journal of Agricultural Economics, 69, 285-92.

[9] NOGUERA MÉNDEZ, P. 1996. «El patrón estacional de los precios y de las producciones hortofrutícolas». Revista española de economía agraria, 178, 35-72.

[10] SANJUÁN, A.I., GIL, J.M. eta ZAPATA, H.O. 1999. «Vertical integration, causation and price transmission in the Spanish hog industry». Galizzi, G. eta Venturini, L. (editoreak): Vertical Relationships and Coordination in the Food System, 611-627. Physica-Verlag.

[11] SANJUÁN, A.I. eta DAWSON, P.J. 2003. «Price Transmission, BSE and Structural Breaks in the UK Meat Sector». European Review of Agricultural Economic, 30, 155-172.

[12] SMITH, C.W. 1990. Auctions: The social construction of value. University of California Press, Oakland.

[13] TIFFIN, R. eta DAWSON, P.J. 2000. «Structural breaks, cointegration and the farm-retail price spread for lamb». Applied Economics, 32, 1281-1286.

[14] VONCRAMON-TAUBADEL, S. 1998. «Estimating Asymmetric price transmission with the error correction representation: An application to the Germanpork market». European Review of Agricultural Economics, 25, $1-18$.

[15] WARD, R.W. 1982. «Asymmetry in Retail, Wholesale, and Shipping Point Pricing for Fresh Vegetables». American Journal of Agricultural Economics Association, 64, 205-212. 